\title{
Strategi Program Pemuliaan Tanaman Kelapa Sawit (Elaeis guinensis Jacq.) pada Lahan Suboptimal di PT Binasawit Makmur
}

\author{
Oil Palm Breeding Program Strategy for Suboptimal Area \\ in PT Binasawit Makmur
}

\author{
Muhammad Antony Jefri Pratama ${ }^{1}$, Nurcahyono Indarto ${ }^{1}$, Fahmi Wendra ${ }^{\left.1,2^{*}\right)}$ \\ Victor Manotar Pademan Manalu ${ }^{1}$, Agry Widya Pradipta ${ }^{1}$, Bayu Lesmana ${ }^{1}$, Upit \\ Sarimana $^{1}$, Pratiwi Erika ${ }^{1}$, Zulhermana Sembiring ${ }^{1}$, Dwi Asmono ${ }^{1}$ \\ ${ }^{1}$ Departement R \& D PT. Sampoerna Agro, Tbk. Palembang, Sumatera Selatan 30127 \\ ${ }^{2}$ Program Studi Doktor Ilmu Pertanian, Fakultas Pertanian, Universitas Sriwijaya, \\ Sumatera Selatan 30139 \\ ${ }^{*}$ Penulis untuk korespondensi: fahmi.wendra@sampoernaagro.com
}

\begin{abstract}
Suboptimal areas have great potential to be used an alternative land for cultivation of oil palm.We needed superior oil palm material to be able to grow well on that land. PT. Binasawit Makmur (BSM) through the Breeding Unit has developed a strategy regarding the assembly of superior material oil palm drought resistant. The objectives of this research were to introduce, evaluate, and select the genetic material based on productivity components (total and weight of fresh fruit bunches/ha, extraction rate) andhigh increment. In addition, the efforts have been made to obtain drought tolerant material are conducting a progeny trial (DXP Trial) on mature palm to obtain drought tolerant in the dried season. Based on the results of the progeny trial, both of parents were traced to a crossing program. Currently, the seeds of the crossing have been obtained to confirm the results of the research on the nursery scale.In the nursery trial, research will be conduct observe the analysis of proline content, stomata and chlorophyll content.Selection in the mature palm DXP progeny trial was followed by application support technologies tools such as molecular analysis techniques used SSR and SNP. Through this approach, it will be obtain superior genetic material in terms of productivity and also drought tolerance so that it can be used for recombination and release of new varieties.
\end{abstract}

Keywords: drought tolerant, molecular markers, oil palm, suboptimal

\begin{abstract}
ABSTRAK
Areal suboptimal memiliki potensi besar sebagai alternatif lahan untuk budidaya tanaman kelapa sawit. Maka dibutuhkan bahan tanam kelapa sawit unggul yang mampu tumbuh dengan baik pada lahan tersebut. PT. Binasawit Makmur (BSM) melalui Unit Breeding telah menyusun strategi mengenai perakitan bahan tanam kelapa sawit unggul yang tahan terhadap kekeringan. Strategi yang telah dilakukan adalah dengan mengintroduksi, mengevaluasi, dan menyeleksi material genetik berdasarkan komponen produktivitas (jumlah dan berat tandan buah segar/ha, ekstraksi minyak/Ha) dan pertumbuhan tinggi yang melambat. Selain itu, upaya yang telah dilakukan untuk mendapatkan bahan tanam yang toleran kekeringan adalah melakukan percobaan progeni trial (DXP Trial) pada pokok-pokok dewasa untuk mendapatkan progeni-progeni yang toleran pada musim kering. Kemudian berdasarkan hasil percobaan progeni ditelusuri kedua tetuanya untuk dilakukan program persilangan. Saat ini telah didapatkan benih hasil
\end{abstract}


persilangan tersebut untuk dikonfirmasi pada skala pembibitan. Penelitian pada tahap pembibitan akan dilakukan dengan mengamati kandungan proline, stomata dankandungan klorofil. Pada pokok dewasa percobaan progeni DXP seleksi diikuti dengan mengaplikasikan teknologi penunjang seperti teknik analisis molekulermenggunakan SSR dan SNP. Melalui pendekatan ini, akan diperoleh material genetik yang unggul dalam segi produktivitas dan juga toleran kekeringan sehingga dapat digunakan untuk program rekombinasi dan pelepasan varietas baru.

Kata kunci: kelapa sawit, marka molekuler, suboptimal, toleran kekeringan

\section{PENDAHULUAN}

Kelapa sawit merupakan tanaman perkebunan yang popular dan perkembangannya cukup pesat di Indonesia. Perkembangan perkebunan kelapa sawit Indonesia meningkat dari sekitar 300 ribu hektar pada tahun 1980 menjadi 1,12 juta pada tahun 1990 . Peningkatan terus terjadi, pada tahun 2000 meningkat menjadi 4,15 juta hektar dan pada tahun 2013 mencapai 10,4 juta hektar (Direktorat Jendral Perkebunan, 2014). Pada tahun 2016 luas lahan perkebunan kelapa sawit mencapai 11,6 juta hektar (GAPKI, 2018).

Perkembangan perkebunan kelapa sawit mengakibatkan lahan mineral semakin berkurang. Untuk mengimbangi kebutuhan lahan akibat keberadaan lahan mineral yang terbatas, maka alternatif pilihan adalah dengan memanfaatkan lahan suboptimal.

Lahan suboptimal adalah lahan yang telah mengalami degradasi atau lahan yang mempunyai tingkat kesuburan yang rendah sehingga tidak dapat mendukung pertumbuhan tanaman secara optimal. Lahan suboptimal terdiri dari tanah mineral dan tanah rawa.

Tipologi lahan suboptimal yang dapat dimanfaatkan untuk perkebunan kelapa sawit memiliki beberapa kendala kesesuaian lahan. Ritung et. al., (2007) menjelaskan lahan dapat diklasifikasikan menjadi 4 kelas berdasarkan kesesuaiannya yaitu kelas S1 Sangat Sesuai, merupakan lahan yang tidak mempunyai faktor pembatas yang nyata terhadap penggunaan secara berkelanjutan. Kelas S2 Cukup
Sesuai, merupakan lahan yang mempunyai faktor pembatas yang akan berpengaruh terhadap produktivitas tanaman. Kelas S3 Sesuai Marginal, merupakan lahan yang mempunyai faktor pembatas yang berat, dan faktor pembatas ini akan sangat berpengaruh terhadap produktivitasnya. Kelas N Tidak Sesuai karena mempunyai faktor pembatas yang sangat berat atau sulit diatasi. Faktor pembatas yang berpengaruh terhadap produktivitas tanaman kelapa sawit di areal suboptimal adalah kesuburan tanah, iklim, ketersediaan air dan kualitas air. Perubahan iklim global merupakan faktor pembatas yang harus dipertimbangkan karena membuat suhu harian meningkat, kelembaban udara menurun, periodisitas iklim kering semakin pendek, dan kelebihan sinar ultra violet. Akibatnya tanaman akan mengalami cekaman kekeringan dan menyebabnya terjadinya penurunan produktivitas (Sinaga, 2008).

Untuk memacu produktivitas, Sinaga (2008) menjelaskan strategi yang dapat dikembangkan di lahan kering adalah memberikan input yang tinggi dengan memanipulasi lahan, tujuannya agar sesuai untuk pertumbuhan tanaman dan menggunakan varietas tanamanyang adaptif terhadap kondisi lahan kering.

Pemuliaan tanaman adalah kegiatan untuk meningkatkan kualitas tanaman agar diperoleh tanaman yang lebih baik dari sebelumnya sehingga menguntungkan bagi manusia. Riset pemuliaan kelapa sawit Indonesia pada umumnya ditujukan untuk 
menghasilkan bahan tanaman kelapa sawit unggul yang memiliki produktivitas tinggi dan memiliki karakteristik sekunder spesifik seperti kualitas minyak, fenologi, ketahanan terhadap cekaman biotik atau cekaman abiotik (Asmono et al., 2005). Semakin meningkatnya intensitas replanting dan perkembangan areal kelapa sawit ke areal suboptimal, di masa yang akan datang dibutuhkan bahan tanaman yang memiliki toleransi terhadap cekaman biotik dan abiotik, termasuk di antaranya bahan tanaman yang memiliki sifat ketahanan terhadap kekeringan.

BSM yang berkomitmen untuk mengutamakan kepuasan pelanggan melalui Unit Breeding menyusun strategi mengenai perakitan bahan tanam kelapa sawit unggul yang tahan terhadap kekeringan. Tujuannya adalah memperoleh material genetik yang unggul dalam segi produktivitas dan juga toleran kekeringan sehingga dapat digunakan untuk program rekombinasi dan pelepasan varietas baru. Penelitian ini bertujuan untuk mengintroduksi, mengevaluasi, dan menyeleksi material genetik berdasarkan komponen produktivitas (jumlah dan berat tandan buah segar/ha, ekstraksi minyak/Ha) dan pertumbuhan tinggi yang melambat.

\section{BAHAN DAN METODE}

Observasi dilaksanakan di BSM yang berlokasi di Desa Surya Adi, Kecamatan Mesuji, Kabupaten Ogan Komering Ilir. Bahan tanaman yang digunakan adalah tanaman kelapa sawit DXP Trial berjumlah 425 progeni yang terdiri dari 6 varietas yaitu DxP Sriwijaya 1, DxP Sriwijaya 2 DxP Sriwijaya 3, DxP Sriwijaya 4, DxP Sriwijaya 5 dan DxP Sriwijaya 6.

\section{Metode Seleksi}

Metode seleksi secara konvensional dilakukan dengan merekam data seperti data Produksi (5 tahun pertama produksi), Analisa tandan (dimulai akhir tahun kedua produksi), Tinggi (tahun 5 dan 7 setelah penanaman), Diameter batang (lebih kurang 7 tahun setelah penanaman), Pengukuran daun (setiap tahun, dimulai dari 1 tahun setelah penanaman), Produksi pelepah (setiap tahun, dimulai dari 2 tahun setelah penanaman) dan Crown disease (interval 4 bulan, antara tahun 1 sampai tahun 5 setelah penanaman) yang diperlukan untuk memperoleh karakteristik seleksi (Breure \& Verdooren, 1995).

Kandungan proline, stomata dan kandungan klorofil juga diamati pada kondisi tanah cukup air dan kekurangan kadar air. Data pengamatan tersebut akan digunakan dalam seleksi berdasarkan marka molekuler.

Metode seleksi analisis molekuler dapat dilakukan dengan menggunakan Marka Molekuler Mikrosatelit atau Simple Sequence Repeats (SSRs) menggunakan mesin PCR (Polymerase Chain Reaction). Analisis data dilakukan berdasarkan hasil scoring pola pita DNA yang muncul pada gel akrilamida.

Metode seleksi analisis molekuler lainnya adalah dengan menggunakan Marka Molekuler Single Nucleotide Polymorphisms (SNPs). Identifikasi SNPs dilakukan secara komputasional dengan program komputer. Terdapat beberapa program yang telah tersedia dengan spesifikasi yang berbedabeda yang dirancang untuk data berukuran besar yang dihasilkan dari sequencing DNA genom total dengan teknologi NGS. Keseluruhan marka yang digunakan akan diasosiasikan dengan karakter produksi serta karakter pendukung untuk ketahanan terhadap kekeringan.

\section{HASIL DAN PEMBAHASAN}

Introduksi material merupakan faktor penting dalam program pemuliaan tanaman. Introduksi berperan dalam mendapatkan induk-induk baru yang memiliki sifat-sifat unggul baru untuk menghasilkan varietas unggul. Intoduksi juga berperan untuk menjaga keragaman genetik. 


\section{Introduksi Material di BSM}

BSM memulai program pemuliaan dengan mengintroduksi populasi besar yang memiliki keragaman genetik tinggi, baik dari tetua betina dan tetua jantan. Materi tersebut berupa pohon-pohon induk dura selfings (225 famili) yang diseleksi dan diintroduksi dari ASD Costa Rica. Material dura tersebut berasal dari lima pusat program pemuliaan di dunia yaitu Dami (Papua Nugini), Chemara (Malaysia), MARDI (Malaysia), dan Harrison \& Crosfield (Malaysia) dan Socfin (Malaysia). Sumber tetua jantan berupa pohon-pohon pisifera yang berasal dari persilangan TxP terdiri atas 7 origin(50 famili) yaitu origin Avros, Ghana, Ekona, Dami komposit, Yangambi, $\mathrm{La} \mathrm{Me}$, dan Nigeria.

\section{Evaluasi}

Proses penanaman dan evaluasi seluruh progeni (425 progeni) membutuhkan waktu yang cukup lama. Untuk mengeluarkan efek-efek dari periode penanaman dan waktu evaluasi pertumbuhan terhadap kinerja progeni, upaya yang dilakukan BSM adalah dengan menggunakan desain percobaan yang tidak biasa, yaitu desain blok tidak sempurna (incomplete blocks design). Sesuai dengan kaidah desain alfa, percobaan tidak menggunakan varietas pembanding spesifik. Keragaan famili-famili terbaik dapat dibandingkan dengan rataan umum seluruh progeni. Progeni-progeni dura $\mathrm{x}$ pisifera ditanam dengan 3 replikasi dan plot-plot yang terdiri atas 16 pohon masingmasing dari ketiga replikasi dibagi lagi menjadi blok-blok yang lebih kecil yang terdiri atas 9 progeni dan yang dikelompokkan ke dalam waktu tanam yang sama.

\section{Metode Seleksi}

Pewarisan sifat yang rendah untuk beberapa karakteristik (terutama produksi tandan) mengakibatkan proses seleksi tidak efektif, maka untuk mengevaluasi suatu famili kelapa sawit dapat diestimasi secara akurat dengan memperhatikan nilai Daya
Gabung Umum (DGU) tetua tetuanya. (Breure \& Bos, 1992). Nilai nilai dapat diestimasi dari hasil evaluasi progeni persilangan dura $\mathrm{x}$ pisifera, dengan catatan skema penyilangan terkoneksi (Breure \& Konimor, 1992).

Berdasarkan hasil evaluasi dan analisis data didapatlah nilai DGU hingga nilai fenotipik individu. Nilai-nilai inilah yang dijadikan acuan untuk menentukan hasil seleksi baik ditingkat famili maupun ditingkat individu. Karakteristik diklasifikasikan berdasarkan titik rataan (mean) dan simpangan baku (standart deviation) kemudian dilakukan pembobotan sesuai dengan karakteristik yang diinginkan.

\section{Secara Konvensional}

Dalam dan seleksi ada beberapa karakter yang perlu di amati yaitu karakter generatif berupa produksi, karakter vegetatif berupa kecepatan meninggi dan panjang pelepah dan Analisa tandan (minyak) berupa produksi minyak dan oil extract rendement (OER). Karakter tersebut dianggap penting karena riset pemuliaan kelapa sawit Indonesia pada umumnya ditujukan untuk menghasilkan bahan tanaman kelapa sawit unggul yang memiliki produktivitas tinggi dan memiliki karakteristik sekunder spesifik seperti kualitas minyak dan fenologi (Asmono et al., 2005). Menurut Breure \& Verdooren (1995) dalam bukunya menjelaskan data Produksi, Analisa dan tinggi tanaman diperlukan untuk memperoleh karakteristik seleksi.

Data-data berikut diperoleh dari data rata-rata progeni-progeni berdasarkan kriteria seleksi. Progeni-progeni tersebut di kelompokkan berdasar origin tetua pisiferanya sehinngga membentuk varietas. Varietas Sriwijaya 1 berasal dari origin Nigeria, varietas Sriwijaya 1 berasal dari origin Nigeria, varietas Sriwijaya 2 berasal dari origin Ghana, varietas Sriwijaya 3 berasal dari origin Ekona, varietas Sriwijaya 4 berasal dari origin Avros varietas Sriwijaya 5 berasal dari origin 
Dami dan varietas Sriwijaya 6 berasal dari origin Yangambi.

\section{a. Karakter Generatif}

Pengamatan karakter generatif merupakan proses pencatatan data karakterkarakter yang berhubungan dengan reproduksi dan potensi hasil tanaman. Pengamatan ini merupakan indikator suatu tanaman dinyatakan memiliki produktivitas yang tinggi. Pada observasi ini karakater pengamatan yang digunakan untuk menilai produktivitas adalah jumlah tandan (tandan/tahun), berat tandan ( $\mathrm{kg} /$ tandan) dan produksi (ton/ha). Berikut adalah hasil pengamatan generatif berupa pengamatan produksi (Tabel 1.):

Tabel 1. Hasil evaluasi varietas DxP Sriwijaya berdasarkan karakakter generatif.

\begin{tabular}{lccc}
\hline Varietas & $\begin{array}{c}\text { Rata-rata Jumlah } \\
\text { Tandan (tandan/tahun) }\end{array}$ & $\begin{array}{c}\text { Rata-rata Berat Tandan } \\
\text { (kg/tandan) }\end{array}$ & $\begin{array}{c}\text { Rata-rata Produksi } \\
\text { (ton/ha) }\end{array}$ \\
\hline Sriwijaya 1 & 19 & 11,5 & 32,20 \\
Sriwijaya 2 & 18 & 11,4 & 29,80 \\
Sriwijaya 3 & 19 & 10,8 & 30,50 \\
Sriwijaya 4 & 15 & 12,5 & 27,70 \\
Sriwijaya 5 & 19 & 11,1 & 30,90 \\
Sriwijaya 6 & 17 & 12,2 & 29,50 \\
\hline
\end{tabular}

*umur 8 tahun

Berdasarkan data produksi varietas yang memiliki rata-rata produksi tertinggi adalah varietas Sriwijaya 1 yaitu 32,20 ton/ha dengan jumlah tandan rata-rata 19 tandan/tahun dan rata-rata berat tandan 11,5 $\mathrm{kg}$. Produksi terendah adalah varietas Sriwijaya 6 yaitu 29,50 ton/ha dengan jumlah tandan rata-rata 17 tandan/tahun dan rata-rata berat tandan $12,2 \mathrm{~kg}$. Data di atas berasal dari rata-rata produksi progeniprogeni yang memiliki tetua pisifera yang sama di kelompokkan berdasar originnya.Progeni-progeni yang memiliki produksi di atas rata-rata akan di seleksi kembali berdasarkan karakter seleksi lainnya.

\section{b. Karakter Vegetatif}

Pengamatan karakter vegetatif merupakan proses pengamatan pertumbuhan vegetatif tanaman. Pada observasi ini karakter yang diinginkan adalah tanaman yang memiliki pelepah yang pendek serta memiliki kecepatan meninggi yang lambat. Berikut adalah hasil pengamatan vegetatif berupa pengamatan panjang pelepah dan kecepatan meninggi (Tabel 2):

Tabel 2. Karakter vegetatif kelapa sawit varietas DxP Sriwijaya berdasarkan panjang pelepah dan kecepatan meninggi.

\begin{tabular}{lcc} 
Varietas & Panjang Pelepah $(\mathbf{c m})$ & Tinggi Tanaman $(\mathbf{c m})$ \\
\hline Sriwijaya 1 & 575 & 292 \\
Sriwijaya 2 & 551 & 446 \\
Sriwijaya 3 & 609 & 413 \\
Sriwijaya 4 & 559 & 478 \\
Sriwijaya 5 & 528 & 398 \\
Sriwijaya 6 & 583 & 435 \\
\hline
\end{tabular}

*umur 8 tahun 
Berdasarkan data pengamatan varietas yang memiliki pelepah terpendek adalah varietas Sriwijaya 5 yaitu $528 \mathrm{~cm}$ dengan tinggi $398 \mathrm{~cm}$ diusia ke delapan tahun. Sementara itu, varietas yang memiliki tinggi terendah adalah varietas Sriwijaya 1 dengan panjang pelepah 575 $\mathrm{cm}$. Sama halnya dengan data generatif Data vegetatif juga berasal dari rata-rata produksi progeni-progeni yang memiliki tetua pisifera yang sama di kelompokkan berdasar originnya. Progeni-progeni yang memiliki produksi di atas rata-rata akan di seleksi kembali berdasarkan karakter seleksi lainnya.

\section{c. Analisa Tandan}

Selain produksi indikator suatu tanaman dinyatakan memiliki produktivitas yang tinggi adalah memiliki produksi minyak yang tinggi. Pada indikator ini karakater pengamatan yang digunakan adalah rata-rata oil extract rendement (OER) dan rata-rata produksi minyak (ton/ha). Berikut adalah hasil pengamatan generatif berupa pengamatan analisa tandan (Tabel 3):

Tabel 3. Produksi minyak tanaman kelapa sawit varietas DxP Sriwijaya.

\begin{tabular}{lcc}
\hline Varietas & Rata-rata OER $(\boldsymbol{\%})$ & $\begin{array}{c}\text { Rata-rata Produksi Minyak } \\
\text { (ton/ha) }\end{array}$ \\
\hline Sriwijaya 1 & 25 & 8,15 \\
Sriwijaya 2 & 27 & 7,96 \\
Sriwijaya 3 & 24 & 7,20 \\
Sriwijaya 4 & 24 & 6,65 \\
Sriwijaya 5 & 26 & 7,91 \\
Sriwijaya 6 & 24 & 7,20 \\
\hline
\end{tabular}

*umur 8 tahun

Berdasarkan data Analisa tandan, varietas yang memiliki rata-rata produksi minyak tertinggi adalah varietas Sriwijaya 1 yaitu 8,15 ton/ha dengan OER mencapai $25 \%$. Produksi minyak terendah adalah varietas Sriwijaya 4 yaitu 6,65 ton/ha dengan OER mencapai $25 \%$.

\section{Proline}

Proline adalah asam amino yang disintesis dari hasil fosforilasi glutamat. Jumlah proline yang meningkat diduga merupakan indikasi toleransi terhadap stres kekeringan. Kurnia dan Suprihati (2016) menyimpulkan cekaman kekeringan dapat meningkatkan kadar proline, keberadaan proline dapat menjadi penanda ketahanan tanaman gandum terhadap cekaman. hal ini dibuktikan dari hasil penelitianya bahwa terdapat perbedaan jumlah akumulasi proline pada fase pertumbuhan yang berbeda diberbagai varietas gandum saat mengalami cekaman.

Kandungan proline merupakan salah satu karakter seleksi dalam observasi ini. Pada pelaksanaannya untuk dapat melihat perbedaan jumlah akumulasi proline secara jelas progeni-progeni yang ada dibagi menjadi 2 perlakuan yaitu irigasi dan tanpa irigasi. Berikut adalah hasil analisa kandungan proline yang di ambil pada tahun 2016 dan 2017 (Tabel 4):

Tabel 4. Analisa kandungan proline pada tanaman kelapa sawit varietas DxP Sriwijaya.

\begin{tabular}{lcc}
\hline Perlakuan & $\begin{array}{c}\text { Rata-rata Kandungan Proline } \\
\text { Tahun 2016 } \\
(\boldsymbol{\mu g} / \mathbf{g} \text { sample) }\end{array}$ & $\begin{array}{c}\text { Rata-rata Kandungan } \\
\text { Proline Tahun 2017 } \\
(\boldsymbol{\mu g} / \mathbf{g} \text { sample) }\end{array}$ \\
\hline irigasi & 12,36 & 27,39 \\
tanpa irigasi & 13,21 & 27,18 \\
\hline
\end{tabular}


Berdasarkan hasil analisa yang dilakukan tidak terdapat perbedaan jumlah akumulasi proline yang jelas pada kedua perlakuan baik pada perlakuan irigasi maupun perlakuan tanpa irigasi. Sehingga hal ini membuat hasil analisa kandungan proline sebagai karakter seleksi tidak dapat digunakan sebagai karakter seleksi.

\section{Stomata}

Salah satu respon tanaman saat kondisi defisit air adalah menutup stomata. Hal ini dilakukan tanaman untuk mengurangi kehilangan air akibat laju transpirasi. Pada tanaman yang mengalami cekaman kekeringan jumlah stomata akan mengalami penurunan, hal ini dibuktikan oleh Hidayati et. al., (2017) yang melakukan penelitian pada tanaman Nyamplung dan Johar. Kesimpulan yang di dapat adalah tanaman Johar Bondowoso dan NTT lebih adaptif terhadap kekeringan dibandingkan dengan tanaman Nyamplung Baluran dan Madura, hal ini dikarenakan perlakuan kekeringan pada tanaman Nyamplung Baluran dan Madura menunjukkan penurunan indeks stomata pada tanaman tersebut. Berikut adalah data jumlah stomata yang terbuka dan tertutup pada perlakuan irigasi dan non irigasi yang dilakukan dalam observasi ini (Tabel 5):

Tabel 5. Jumlah stomata pada perlakuan irigasi dan non irigasi di tanaman kelapa sawit varietas DxP Sriwijaya.

\begin{tabular}{lccc}
\hline \multicolumn{1}{r}{ Stomata } & Stomata Terbuka & Stomata Tertutup & Total \\
\hline irigasi & 56,08 & 154,64 & 210,72 \\
tanpa irigasi & 40,58 & 172,52 & 213,10 \\
\hline
\end{tabular}

Berdasarkan hasil pengamatan yang dilakukan, terlihat bahwa jumlah stomata yang tertutup pada perlakuan non irigasi lebih banyak dibandingkan dengan perlakuan irigasi. Artinya, terdapat beberapa progeni yang memberikan respon mekanisme pertahanan diri terhadap perlakuan yang diberikan dalam upaya mencegah kehilangan air akibat laju transpirasi. Berikut adalah beberapa progeni yang memiliki persentase jumlah stomata tertutup berdasarkan jumlah terbanyak pada perlakuan non irigasi yang diduga memiliki mekanisme pertahanan diri terhadap cekaman kekeringan (Tabel 6):

Tabel 6. Progeni yang memiliki persentase jumlah stomata tertutup dengan jumlah terbanyak.

\begin{tabular}{ccccc}
\hline Progeni & Perlakuan & Stomata Terbuka & Stomata Tertutup & Persentase \\
\hline 008 & NI & 23 & 956 & $98 \%$ \\
375 & NI & 32 & 857 & $96 \%$ \\
135 & NI & 50 & 862 & $95 \%$ \\
078 & NI & 59 & 815 & $93 \%$ \\
085 & NI & 53 & 729 & $93 \%$ \\
827 & NI & 72 & 773 & $91 \%$ \\
754 & NI & 95 & 905 & $91 \%$ \\
168 & NI & 74 & 652 & $90 \%$ \\
467 & NI & 91 & 796 & $90 \%$ \\
797 & NI & 114 & 980 & $90 \%$ \\
\hline
\end{tabular}


Berdasarkan hasil data di atas progeni-progeni tersebut akan di ranking berdasarkan titik rataan (mean) dan simpangan baku (standart deviation) kemudian dilakukan pembobotan sesuai dengan karakteristik yang diinginkan dan akan dijadikan sebagai acuan untuk menentukan hasil seleksi baik ditingkat famili maupun ditingkat individu.

\section{Kandungan klorofil}

Klorofil merupakan komponen utama kloroplas dalam proses fotosintesis. Guo and Li (1996) dalam Li et. al. (2006) menyatakan bahwa kandungan klorofil relatif memiliki hubungan positif terhadap laju fotosintesis. Li et. al. (2006) dalam penelitian menemukan bahwa kandungan klorofil pada kondisi defisit air mengalami penurunan. Hal ini sesuai penelitian yang dilakukan Nio dan Yunia (2011) yang menyatakan bahwa pada umumnya respons tanaman terhadap kekurangan air ditunjukkan dengan terjadinya penurunan konsentrasi klorofil daun sehingga dapat dipakai sebagai indikator tanaman toleransi terhadap defisit air. Berikut hasil analisa kandungan klorofil pada perlakuan irigasi dan non irigasi yang dilakukan dalam observasi ini (Tabel. 7):

Tabel 7. Kandungan klorofil pada perlakuan irigasi dan non irigasi di tanaman kelapa sawit varietas DxP Sriwijaya.

\begin{tabular}{lc}
\hline \multicolumn{1}{c}{ Perlakuan } & chl Total $(\mathbf{m g} / \mathbf{g})$ \\
\hline irigasi & 15,58 \\
tanpa irigasi & 15,13 \\
\hline
\end{tabular}

Berdasarkan hasil analisa yang dilakukan tidak terdapat perbedaan pada kandungan klorofil baik pada perlakuan irigasi maupun perlakuan tanpa irigasi. Sehingga hal ini membuat hasil analisa kandungan klorofil tidak dapat digunakan sebagai karakter seleksi.

\section{Kejadian Kemarau}

Terjadinya kemarau panjang pada tahun 2004 dan 2006 menyebabkan terjadinya defisit air sehingga mengakibat terjadinya penurunan produksi. BSM melihat adanya peluang untuk menjadikan kejadian tersebut sebagai tambahan kriteria seleksi. Sehingga produksi di tahun 2005 dan 2007 ditambahkan sebagai kriteria seleksi tambahan. Berikut adalah data ratarata produksi 10 tahun dan rata-rata produksi tahun 2005 dan 2007 pada beberapa progeni DxP Sriwijaya (Tabel 8):

Tabel 8. Rata-rata produksi 10 tahun dan rata-rata produksi tahun 2005 dan 2007 pada beberapa progeni DxP Sriwijaya.

\begin{tabular}{cccc}
\hline Progeni & Mean 10 Years & Mean 2005 \& 2007 & Origin \\
\hline 208 & 159,5 & 130,5 & Nigeria \\
808 & 158,7 & 131,5 & Nigeria \\
377 & 157,5 & 128,0 & Nigeria \\
284 & 156,0 & 129,3 & Ekona \\
626 & 154,4 & 129,7 & Dami \\
628 & 154,3 & 142,0 & Ekona \\
527 & 153,1 & 131,5 & Ghana \\
816 & 152,7 & 130,9 & Dami \\
467 & 151,8 & 121,2 & Ekona \\
945 & 151,5 & 122,1 & Ghana \\
\hline
\end{tabular}




\section{Pengujian di pembibitan}

Berdasarkan kriteria seleksi berupa karakter generatif, karakter vegetatif, Analisa tandan, kandungan proline, stomata, kandungan klorofil dan kejadian kemarau di tahun 2004 dan 2006 terpilih 12 progeni yang memiliki karakteristik yang diinginkan (Tabel 8), progeni-progeni ini disilangkan untuk kemudian dapat dikecambahkan dan dikonfirmasi di pembibitan (Tabel 9).

Tabel 9. Kandidat progeni untuk konfirmasi pengujian di pembibitan.

\begin{tabular}{cclc}
\hline No & Progeni & Origin & Rata-rata Produksi 10 Tahun (kg/palm) \\
\hline 1 & 365 & Avros & 127,3 \\
2 & 314 & Lame & 123,0 \\
3 & 284 & Ekona & 122,8 \\
4 & 945 & Ghana & 151,5 \\
5 & 816 & Dami Komposit & 152,7 \\
6 & 626 & Dami Komposit & 154,4 \\
7 & 247 & Avros & 119,7 \\
8 & 377 & Nigeria & 157,5 \\
9 & 797 & Ghana & 144,0 \\
10 & 008 & Nigeria & 145,3 \\
11 & 505 & Avros & 121,8 \\
12 & 665 & Dami Komposit & 142,8 \\
\hline
\end{tabular}

*SPH 135 pokok/ha

\section{Penggunaan Marka Molukuler}

Penggunaan teknologi genomik berupa Marker Assisted Selection (MAS) di BSM terus berkembang dari waktu ke waktu. Penggunaannya pada tanaman kelapa sawit yang mempunyai siklus hidup yang panjang dan kebutuhan lahan yang luas untuk keperluan observasi di lapangan, menjadikan teknologi ini sebagai pilihan ideal untuk menjadi salah satu alternatif. Sehingga proses seleksi dapat dipercepat dan akan ada peningkatan nilai tambah dari suatu material kelapa sawit.

Sebagai langkah awal, BSM saat ini sedang mengoleksi DNA seluruh material genetik. Aplikasi lebih lanjut untuk MAS ini dapat dilakukan melalui beberapa pilihan metode diantaranya Random Amplified PolymorphicDNA (RAPD), analisis isozim, Single Sequence Repeat (SSR), Single Nucleotide Polymorphism (SNP), Restriction Fragment Length Polymorphism (RFLP), Amplified Fragment Length Polymorphism (AFLP). Koleksi DNA yang telah diisolasi dan mengandung semua informasi genetik tanaman, memungkinkan kegiatan seleksi dapat dilakukan tanpa menunggu masa produktif tanaman sehingga dapat mempercepat siklus pemuliaan. Namun demikian, observasi terhadap data fenotipik tanaman tetap disarankan dilakukan sebagai verifikasi dan penyediaan data pendukung (Yulismawati, et. al., 2012). Hal ini berkaitan dengan metode seleksi yang dilakukan yaitu mengasosiasikan data genotipik dari marka molekuler dengan data fenotipik dilapangan, sehingga akan didapatkan pokok-pokok yang memiliki sifat unggulan baik secara genotip maupun fenotip.

\section{KESIMPULAN}

1. BSM menyadari akan pentingnya plasma nutfah sebagai landasan pemuliaan dan sebagai landasan pengembangan sistem pembenihan kelapa sawit di Indonesia. Karnanya, BSM mengintroduksi material yang merupakan faktor penting untuk mendapatkan induk-induk baru yang 
memiliki sifat-sifat unggul guna kemajuan keragaman genetik.

2. Seleksi yang tepat terhadap kandidat material yang akan digunakan merupakan kunci keberhasilan program pemuliaan dalam merakit varietas unggul baru.

3. Penggunaan teknologi genomik berupa Marker Assisted Selection (MAS akan sangat membantu efektifitas dan efisiensi seleksi dengan tetap menjadikan hasil observasi terhadap data fenotipik tanaman di lapangan sebagai verifikasi.

\section{UCAPAN TERIMA KASIH}

Ucapan terimakasih penulis sampaikan kepada PT. Sampoerna Agro Tbk. melalui anak perusahaanna PT. Binasawit Makmur dan semua pihak yang memberikan dukungan dalam penulisan makalah ini, baik dukungan moril, tenaga, ilmu, dana maupun doa.

\section{DAFTAR PUSTAKA}

Asmono D, A R Purba, Y Yenni, M Kohar, $\mathrm{H}$ Zaelanie, T Liwang, A B Beng. 2005. Peta dan Prospek Pemuliaan dan Industri Perbenihan Kelapa Sawit Indonesia. Simposium Nasional dan Kongres V PERIPI, Purwokerto, 25-27 Agustus 2005.

Breure CJ and Bos I. (1992). Development of elite families in oil palm (Elaeis guineensis Jacq.). Euphytica 64, 99 $-112$.

Breure CJ and Foster HL. (2003). Responses of Yield, Growth and Leaf Nutrient Levels To N,P, K, and Mg Fertilizers on Two Soil Series in South Sumatra. Proceedings of the 2002 International Oil Palm Conference, Bali, Indonesia.

Breure CJ and Konimor J. (1992). Parent selection for oil palm clonal seed gardens. Di dalam: Proceedings of the 1990 ISPOB International Workshop on Yield Potential in the
Oil Palm, 122-144. Malaysia, Kuala Lumpur, International Society of Oil Palm Breeders and Palm Oil Research Institute.

Breure CJ and Verdooren LR. (1995). Guidelines for testing and selecting parent palms in oil palnm. Practical aspects and statistical methods. ASD Oil Palm Papers 9, 1-68.

Direktorat Jendral Perkebunan. 2014. Statistik Perkebunan Indonesia Komoditas Kelapa Sawit 20132015. Jakarta: Direktorat Jenderal Perkebunan.

GAPKI. 2018. Perkembangan Mutakhir Industri Minyak Sawit Indonesia. https://gapki.id/news/3971/perkemb angan-mutakhir-industri-minyaksawit-indonesia\#more-3971(di akses Oktober 2018).

Guo P, Li M. 1996. Studies on photosynthetic characteristics in rice hybrid progenies and their parents. I. chlorophyll content, chlorophyllprotein complex and chlorophyll fluorescence kinetics. Di dalam: Li, $\mathrm{R}, \mathrm{P}$ Guo, $\mathrm{M}$ Baum, $\mathrm{S}$ rando, $\mathrm{S}$ Ceccarelli. 2006. Evaluation of Chlorophyll Content and Fluorescence Parameters as Indicators of Drought Tolerance in Barley. Agricultural Sciences in China 5(10): 751-757.

Kurnia T D dan Suprihati. 2016. Proline Sebagai Penanda Ketahanan Kekeringan dan Salinitas Pada Gandum. https://www.researchgate. net/ publication/ 303971617 (di akses November 2018).

Li R, P Guo, M Baum, S rando, $\mathrm{S}$ Ceccarelli. 2006. Evaluation of Chlorophyll Content and Fluorescence Parameters as Indicators of Drought Tolerance in Barley. Agricultural Sciences in China 5(10): 751-757.

Nio S A dan Yunia B. 2011. Konsentrasi Klorofil Daun Sebagai Indikator Kekurangan Air Pada Tanaman. 
Jurnal Ilmiah Sains. 11(2), Oktober 2011.

Ritung S, Wahyunto, Agus F, Hidayat $\mathrm{H}$. 2007. Panduan Evaluasi Kesesuaian Lahan dengan Contoh Peta Arahan Penggunaan Lahan Kabupaten Aceh Barat. Bogor:Balai Penelitian Tanah dan World Agroforestry Centre (ICRAF).

Yulismawati Y Puspitanigrum, N Indarto, M R Sirait, AP Raganata, 1 DA
Silomba, Z Sembiring. 2012. Exploiting Cameroon Germplasmthrough Integration of Conventional and Molecular Breeding. Seminar Nasional dan Kongres MAKSI 4 Akselerasi Inovasi Industri Kelapa Sawit untuk Meningkatkan Daya Saing Global. IPB International Convention Center, Bogor, Indonesia. 